\title{
Vibrator Device
}

National Cancer Institute

\section{Source}

National Cancer Institute. Vibrator Device. NCI Thesaurus. Code C50265.

A mechanical device designed to create a vibratory motion. 